\title{
PKM PENDAMPINGAN KEWIRAUSAHAAN UKM KERAJINAN ANYAMAN PANDAN DESA ALUE DUA MUKA O MENGHADAPI ERA NEW NORMAL
}

\author{
${ }^{1 *}$ Muhammad Fuad, ${ }^{2}$ Rini Mastuti, ${ }^{3}$ Yani Rizal \\ Universitas Samudra, Aceh, Indonesia \\ Email : *muhammadfuad@unsam.ac.id
}

\begin{abstract}
Manuskrip: September -2021; Ditinjau: Oktober -2021; Diterima: Oktober -2021; Online: Januari-2022; Diterbitkan: Januari-2022
\end{abstract}

\begin{abstract}
ABSTRAK
Krisis global berupa pandemi Covid-19 telah memunculkan tatanan dunia baru yang disebut era new normal. Tatanan baru ini memunculkan sejumlah persaingan usaha baru terutama penggunaan media pemasaran berbasis digital. Tantangan ini sangat dirasakan khususnya bagi UKM. Tujuan kegiatan PKM ini adalah mendorong sikap kewirausahaan dari Mitra yaitu UKM kerajinan anyaman pandan di Desa Alue Dua Muka O sebagai satu sentra unggulan di Kabupaten Aceh Timur melalui peningkatan kemampuan memanfaatkan strategi logo dagang dan pemasaran digital demi mempertinggi berdaya saing. Kegiatan pendampingan ini dijalankan melalui metode ceramah saat penyampaian materi serta memberikan motivasi kepada mitra, metode diskusi agar terjadi komunikasi dua arah antara tim PKM dan mitra, metode demonstrasi agar mitra mudah memahami aplikasi dari materi yang disampaikan, metode praktik langsung agar mitra mengaplikasikan sendiri materi yang telah didapatkan dengan tetap dibawah bimbingan tim PKM, serta metode pengamatan untuk mengevaluasi dampak kegiatan terhadap daya saing usaha mitra. Hasil pendampingan menunjukkan saat ini mitra telah memiliki identitas logo usaha serta media pemasaran digital seperti WhatsApp, Instagram dan Website usaha. Ketrampilan dalam pemanfaatan media-media tersebut terus mengalami peningkatan, yang selanjutnya mendorong hasil penjualan. Ekspektasi untuk mampu mendukung daya saing produk dan memperluas cakupan pasar keluar daerah juga semakin bisa dicapai saat menghadapai era new normal.
\end{abstract}

Kata Kunci: Kewirausahaan, Logo Usaha, Pemasaran Digital, UKM, Desa Alue Dua Muka O

\section{PENDAHULUAN}

Tantangan utama yang dihadapi UKM saat ini adalah terkait munculnya perubahaan-perubahan struktural akibat pandemi Covid-19 yang mengarah pada tatanan bisnis baru (Irham, 2020; Agustina, 2020). Diakui secara luas bahwa wabah tersebut telah membawa perubahan signifikan atas perilaku lingkungan usaha dan mengarah pada kondisi yang tidak mungkin kembali pada pola sebelumnya, atau bisa disebut 'new normal' (Juhaeri et al., 2021; Kumala \& Junaidi, 2020). Kondisi 
kompetisi usaha saat ini menjadi lebih mengutamakan teknologi digital, karenanya harus segera direspon oleh UKM agar tidak tergilas oleh era persaingan new normal.

Mitra dari kegiatan PKM ini adalah UKM kerajinan anyaman pandan di Desa Alue Dua Muka O. Desa ini merupakan salah satu wilayah di Kecamatan Idi Rayeuk yang telah dikenal lama dengan produk hasil kerajinan anyaman berbahan baku pandan sebagai salah satu produk unggulan di Kabupaten Aceh Timur (Mufida, 2016; Humas Aceh, 2018). Karena letak geografis desa ini berada dekat dengan pantai, maka banyak terdapat tumbuhan pandan sehingga tidak ada persoalan yang berarti terkait ketersediaan bahan baku utama tersebut. Para pengrajin anyaman pandan di Desa Alue Dua Muka O seluruhnya adalah para ibu rumah tangga, sementara kaum laki-laki mayoritas bekerja sebagai nelayan. Dengan demikian, usaha kerajinan ini diharapkan menjadi sumber tambahan pendapatan keluarga selain hasil penjualan tangkapan laut dari suami mereka. Keahlian menganyam daun pandan yang dimiliki ini merupakan ilmu yang diturunkan secara turun-temurun dari para orangtua sebelumnya. Produk-produk kerajinan yang telah dihasilkan antara lain berupa tikar duduk berukuran besar dan kecil, tikar duduk khusus acara adat atau pesta, sajadah, sandal, tempat pensil, sarung bantal, dompet, dan lain-lain:

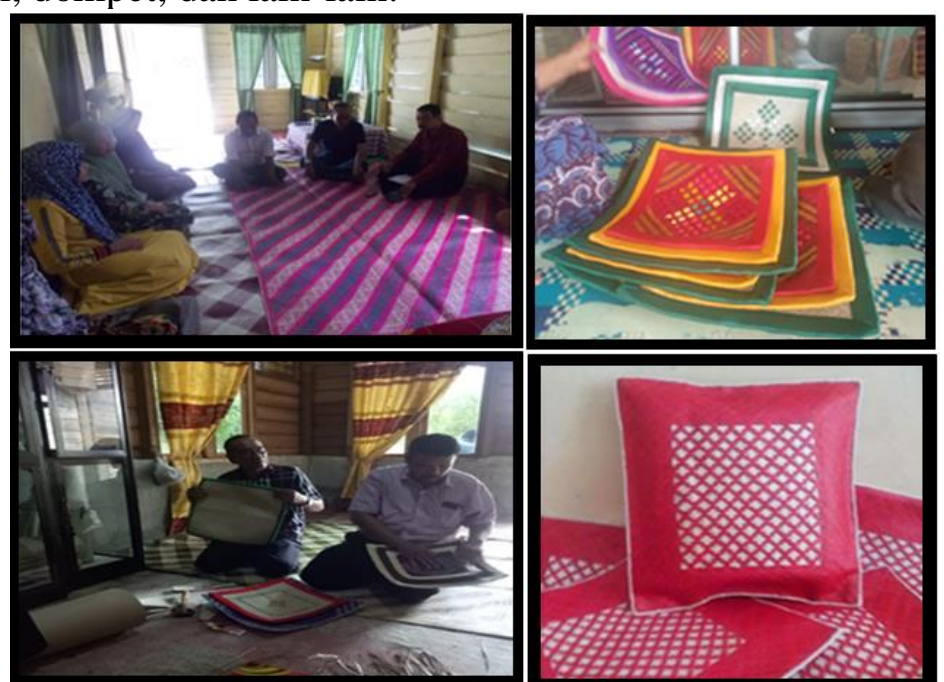

Gambar 1. Wawancara dan Observasi Awal pada Mitra

Berdasarkan hasil observasi dan wawancara awal dengan Ketua dan beberapa anggota kelompok mitra usaha ekonomi produktif dalam kegiatan PKM ini (Gambar 1), proses produksi kerajinan anyaman pandan masih sepenuhnya dikerjakan secara tradisional tanpa mesin (handmade). Dengan kondisi seperti itu, Mitra menghadapi keterbatasan utama berkaitan dengan daya saing produk miliknya. Secara terperinci, hasil analisis situasi di lokasi usaha menunjukkan Mitra mengalami dua permasalahan utama dalam keberlanjutan usahanya, yaitu permasalahan logo usaha, serta permasalahan dalam aktivitas pemasaran produk

METODE PELAKSANAAN KEGIATAN 
Kombinasi metode pendampingan yang dilaksanakan dalam PKM ini adalah sebagai berikut. Pertama adalah metode Ceramah, yang dijalankan saat proses penyampaian materi pendampingan maupun dalam upaya memberikan motivasi. Melalui metode ini diharapkan Mitra bisa memahami tujuan kegiatan dan konsep teoritis dari materi yang diberikan, sehingga terdorong melakukan inovasi produk dan terus bersemangat dalam meningkatkan produktivitas dan menjaga keberlanjutan usaha kerajinan anyaman pandan miliknya.

Metode kedua adalah Diskusi, yang dijalankan saat kegiatan pendampingan berlangsung dengan pola komunikasi dua arah antara Tim PKM selaku pemateri dan Mitra kegiatan. Melalui metode ini diharapkan Mitra lebih memahami materimateri pendampingan secara praktis sehingga membantu dalam proses implementasinya. Ketiga yaitu metode Demonstrasi, digunakan saat Tim PKM memberikan contoh pada saat pelatihan, sehingga Mitra dapat dengan mudah memahami cara penerapan dari materi yang disampaikan. Metode ini lebih diprioritaskan secara bertemu langsung dengan Mitra agar lebih mudah dalam pelaksanaannya. Namun bila kondisi penilaian pandemi tidak memungkinkan, maka proses demonstrasi bisa ditunjukkan melalui video Tim PKM yang di share via WA (WhatsApp) atau dikirimkan Link video untuk diunduh oleh Mitra pada Google Drive.

Metode keempat adalah Praktik Langsung, yang dilaksanakan dengan meminta Mitra mengaplikasikan materi-materi pendampingan yang telah didapatkan tentunya masih dibawah bimbingan Tim PKM. Aplikasi metode ini bisa dijalankan dengan cara Mitra mendemonstrasikan langsung di hadapan Tim PKM, atau apabila kondsi pandemi tidak memungkinkan maka Tim PKM meminta Mitra membuat video mengenai cara mengaplikasikan materi pendampingan dan selanjutnya mengirimkan video tersebut via WA atau di share melalui link dari Google Drive. Melalui metode ini, Tim PKM bisa melakukan evaluasi sejauh mana Mitra memahami materi-materi pendampingan yang telah diberikan sebelumnya, dan menentukan langkah-langkah selanjutnya yang dibutuhkan untuk mencapai tujuan dari kegiatan pendampingan ini.

Kelima adalah metode Pengamatan atau Observasi, yang digunakan untuk mengevaluasi kemampuan Mitra baik selama proses pendampingan maupun setelah pendampingan dilaksanakan. Tujuan dari metode ini adalah melihat dampak dari kegiatan pendampingan yang diberikan sehingga dapat meningkatkan daya saing produk maupun manajemen usaha milik Mitra.

Dihubungkan dengan dua permasalahan utama Mitra yang teridentifikasi, kegiatan pendampingan untuk permasalahan desain logo usaha dilaksanakan melalui metode-metode diskusi, praktik langsung, dan pengamatan. Kegiatan ini dilakukan dengan tujuan agar produk kerajinan anyaman pandan milik Mitra memiliki desain logo usaha yang menarik dan informatif sehingga mudah dikenali oleh masyarakat. Dengan demikian, diekspektasikan terjadi peningkatan produktivitas usaha maupun omzet penjualan dan laba atau keuntungan usaha. Desain logo usaha yang tercipta merupakan hasil dari proses diskusi antara Tim PKM dan Mitra. 
Berikutnya, kegiatan pendampingan terkait pemanfaatan media pemasaran digital dilaksanakan melalui metode-metode ceramah, diskusi, demonstrasi, praktik langsung, dan pengamatan. Kegiatan ini dilakukan untuk mendorong Mitra sebagai pelaku usaha kerajinan anyaman pandan memiliki kemampuan memanfaatkan media pemasaran digital secara baik dan professional untuk meningkatkan daya saing produk di pasar khususnya dalam menghadapi kompetisi di era new normal. Peningkatan daya saing produk diekspektasikan akan dapat meningkatkan produktivitas usaha maupun omzet penjualan dan laba atau keuntungannya.

Setelah pelaksanaan pendampingan, Mitra diharapkan mempraktekkan pengetahuan dan keterampilan yang diperolehnya secara langsung dalam aktivitas usahanya. Lebih jauh, Mitra diminta untuk menularkan manfaat-manfaat yang diperolehnya dalam pelaksanaan program PKM ini kepada para rekan pelaku usaha yang lain dalam lingkungannya, seperti mengajarkan tata cara pemanfaatan media pemasaran berbasis digital.

\section{HASIL DAN PEMBAHASAN}

Hasil analisis situasi mengidentifikasi dua permasalahan utama Mitra dalam menghadapi era new normal adalah belum adanya kepemilikan desain logo usaha yang menarik dan informatif agar masyarakat mudah mengenali produk kerajinan anyaman pandan milik Mitra, serta masih rendahnya kemampuan memanfaatkan media pemasaran digital secara baik dan professional untuk memperluas pangsa pasar. Kegiatan PKM ini berfokus pada kedua masalah itu.

Pada saat pelaksanaan kegiatan PKM ini, Desa Alue Dua Muka O berada dalam kondisi Pandemi Covid-19 kategori Kuning (Yellow) sehingga metode kegiatan pendampingan PKM dilakukan secara terkombinasi antara metode pertemuan langsung dengan meotde daring menggunakan media seperti Zoom atau Google Meet, disesuaikan dengan kategori situasi pandemi di wilayah Mitra pada saat suatu tahapan kegiatan dilaksanakan. Pertemuan secara tatap muka langsung dengan Mitra di lokasi usahanya bila memungkinkan direncanakan akan bersifat terbatas dalam jumlah peserta per pertemuan serta dengan tetap menerapkan physical distancing (menjaga jarak antar peserta), mencuci tangan dengan sabun sebelum melaksanakan suatu pertemuan atau kegiatan, dan tetap menggunakan masker selama pertemuan atau kegiatan berlangsung.

Capaian solutif pertama berupa telah terciptanya desain logo usaha milik Mitra. Permasalahan pemasaran ini dinilai juga terkait dengan permasalahan relatif lemahnya daya saing produk kerajinan anyaman pandan milik Mitra yang terindikasi karena produk tersebut belum memiliki logo atau merek yang menjadi ciri khas atau pembeda utama dari produk-produk pesaing yang sejenis sekaligus yang bersifat informatif dan menarik bagi para konsumen sasarannya. Sejumlah hasil penelitian sebelumnya menekankan bahwa adanya logo/merek dan desain kemasan dapat memperkuat daya saing suatu produk untuk berkompetisi dalam pasar sasarannya (Luffarelli et al., 2019; Mazurek, 2019; Khan \& Panwar, 2019). Dengan demikian, agar dapat bersaing terutama menghadapi produk-produk sejenis, maka produk Mitra seharusnya memiliki logo/merek dan desain kemasan 
sebagai identitas unik miliknya.

Pada proses awal sosialisasi, masih terdapat penolakan secara halus dari Mitra terkait manfaat kepemilikan merek pribadi bagi produk mereka. Namun Mitra akhirnya dapat menerima setelah tim pendampingan secara intensif melakukan komunikasi informal untuk menjelaskan manfaat-manfaat yang bisa dinikmati terkait aktivitas pemasaran produk mereka untuk jangka panjang. Apalagi keutamaan suatu usaha memiliki logo atau merek usaha atas produk-produknya juga memperoleh dukungan penuh pemerintah melalui Undang-Undang Republik Indonesia No.15 Tahun 2001 tentang Merek.

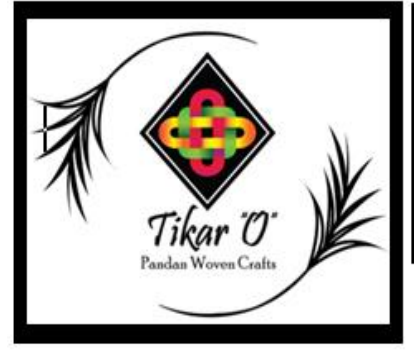

(2a)

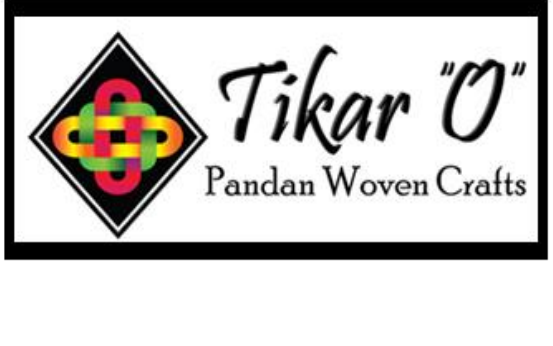

(2b)

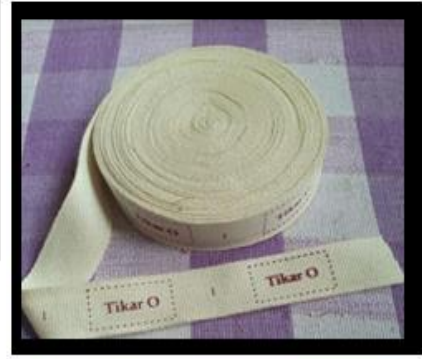

(2c)

Gambar 2. Desain Logo Usaha Mitra

Setelah melakukan diskusi beberapa kali, akhirnya dimunculkan nama merek “Tikar O' yang mencerminkan identitas produk unggulan tikar anyaman pandan yang berasal dari Desa Alue Dua Muka O. Selanjutnya, dijalankan proses desain logo usaha yang disesuaikan dengan keinginan Mitra. Setelah mengalami sejumlah perubahan, akhirnya dicapai kesepakatan untuk logo usaha Mitra (Gambar 2). Tercipta tiga desain logo usaha, yaitu desain memanjang ke bawah (2a), desain memanjang ke samping (2b), desain khusus pada produk tas atau dompet ditempel desain nama merk yang dibordir di atas kain sehingga terbaca nama "Tikar O" saat produk itu dibawa oleh pembeli yang bersangkutan untuk kegiatan-kegiatan tertentu (2c). Dalam penggunaan selanjutnya, merek usaha ini dikombinasikan dengan desain kemasan produk dan registrasi Nomor Induk Berusaha (NIB) (Gambar 3).

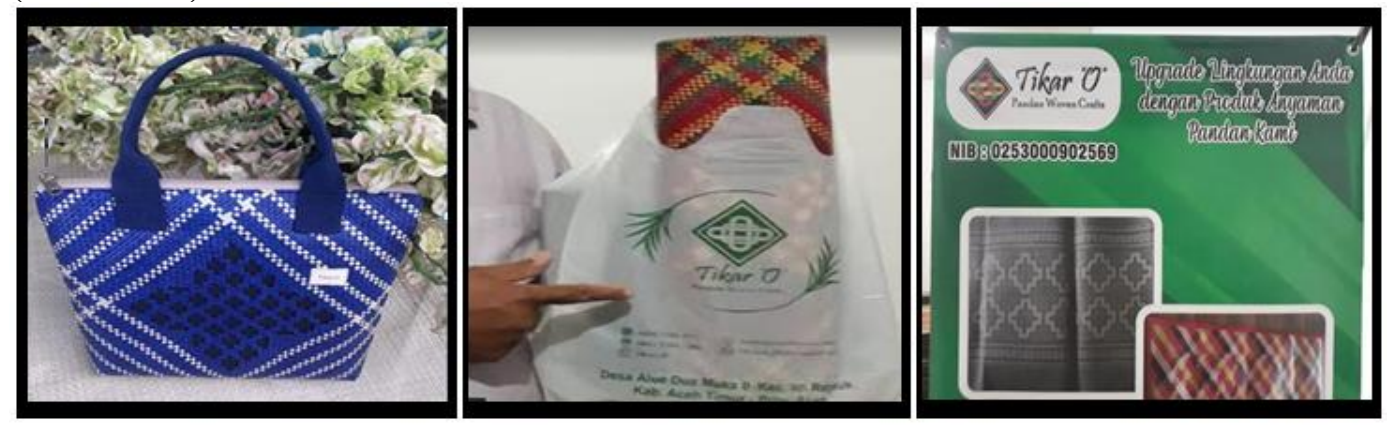

Gambar 3. Aplikasi Logo Usaha Mitra 


\section{HASIL DAN PEMBAHASAN}

Capaian solutif kedua oleh Tim PKM adalah telah tersedianya media pemasaran digital bagi usaha Mitra, salah satunya dengan menggunakan media promosi online berupa website (Haryadi, R. N., et al. 2021) penggunaan onlineshop berbasis website pun dapat dimanfaatkan oleh UMKM untuk dapat menjangkau konsumen yang lebih luas. Selama ini Mitra lebih melaksanakan pemasaran produk secara langsung dimana pembeli atau pelanggan datang ke lokasi usaha untuk memilih produk yang hendak dibelinya, dan kurang intens memanfaatkan jalur pemasaran online walaupun mayoritas anggota dari Mitra memiliki smartphone. Pada saat pandemi Covid-19 melanda yang diikuti kebijakan pemerintah melakukan pembatasan sosial, Mitra terdampak mengalami penurunan signifikan atas omset usaha karena jumlah pembeli yang jauh berkurang. Pemanfaatan teknologi e-commerce karenanya selain mendekatkan produk-produk milik Mitra kepada pasar, sekaligus juga bermanfaat menunjang perluasan cakupan pasar dari produk-produk tersebut (James, 2020; Anggoro et al., 2020; Dumitriu et al., 2019; Taiminen \& Karjaluoto, 2015). Telah adanya desain logo usaha memiliki manfaat penting sebagai identitas produk Mitra saat dilekatkan pada media pemasaran digital tersebut.

Berdasarkan hasil diskusi, Mitra mengharapkan agar tipe teknologi bersifat relatif sederhana. Hal ini karena para anggota kelompok Mitra masih belum memahami penggunakan internet secara baik sehingga merasa kesulitan jika teknologi yang digunakan tergolong canggih. Setelah melakukan evaluasi, akhirnya disepakati untuk memunculkan Instagram dengan alamat “@tikar_o" sebagai media e-commerce untuk produk-produk milik kelompok (Gambar 4). Pada tahap awal ini, desain Instagram masih sederhana. Hal ini dimaksudkan sebagai media pembelajaran awal bagi Mitra. Apabila Mitra sudah dinilai paham, maka desain Instagram dapat dikembangkan lagi agar lebih optimal dalam pemanfaatannya. Patut disyukuri bahwa dalam jangka waktu kurang lebih satu bulan, instagram milik Mitra telah memiliki 181 followers, dan telah mem-posting sebanyak 212 foto produk milik usaha kerajinan anyaman pandan "Tikar O".

Selain itu, Tim Pelaksana PKM juga telah membuatkan website produk usaha bagi Mitra sebagai upaya memperkenalkan lebih banyak produk yang Mitra miliki kepada pasar yang lebih luas di dunia maya (Gambar 5). Alamat website adalah "www.usahakreatifaceh.com". Hanya saja karena baru diluncurkan, maka belum terlihat adanya respon pasar berupa pertanyaan-pertanyaan kepada nomor kontak yang dicantumkan pada website tersebut. Namun optimisme tetap terjaga bahwa website ini akan sangat membantu pertumbuhan bisnis Mitra. 


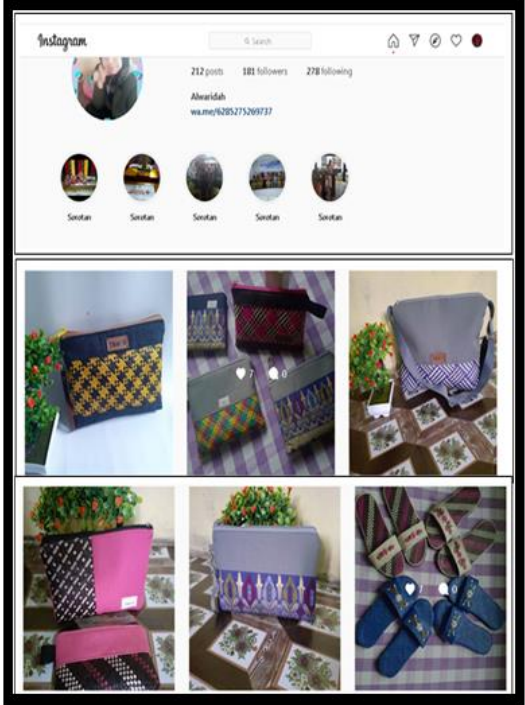

Gambar 4. Instagram Mitra

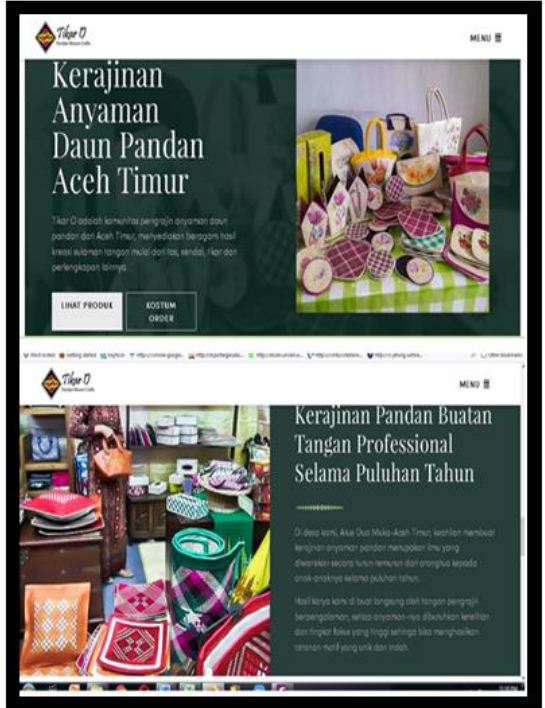

Gambar 5. Website usaha Mitra

Namun disadari perlu adanya peningkatan kemampuan pemanfaatan media e-commerce ini oleh para anggota kelompok kerajinan anyaman pandan serta penentuan strategi digital marketing yang tepat agar produk-produk milik Mitra diketahui oleh cakupan pasar yang lebih besar, yang selanjutnya diharapkan mendorong peningkatan volume penjualannya dan pada akhirnya mendorong tingkat kesejahteraan dari para pelaku usaha kerajinan anyaman pandan yang tergabung dalam usaha "Tikar O".

Hasil evaluasi selama 8 (delapan) periode mulai bulan Maret sampai Oktober 2021 sejauh ini dinilai Mitra mulai memperoleh manfaaat dari kegiatan pendampingan ini yaitu mulai dikenalnya merek "Tikar O" baik di pasar Kabupaten Aceh Timur maupun pasar di sejumlah daerah di wilayah Provinsi Aceh. Dampak selanjutnya adalah trend mulai meningkatnya omset penjualan produk milik Mitra dibandingkan saat awal pelaksanaan Program PKM ini walau terjadi fluktuasi selama rentang 8 bulan tersebut (Gambar 6).

Walau telah terjadi peningkatan, namun nilai omset penjualan ini dirasa kurang menguntungkan mengingat usaha Mitra adalah usaha bersama dengan anggota sebanyak 18 orang yang tentu mengharapkan hasil omset yang lebih besar agar memperoleh bagian keuntungan yang lebih besar untuk membantu perekonomian keluarga. Lebih jauh, kenaikan omset ini dinilai masih bisa ditingkatkan mengingat penurunan nilai omset bisnis Mitra telah menurun sekitar $60 \%$ pada bulan Juni, dimana pemerintah memberlakukan physical distancing dan social distancing secara ketat, dan sekarang masih ada bayang-bayang PPKM. 


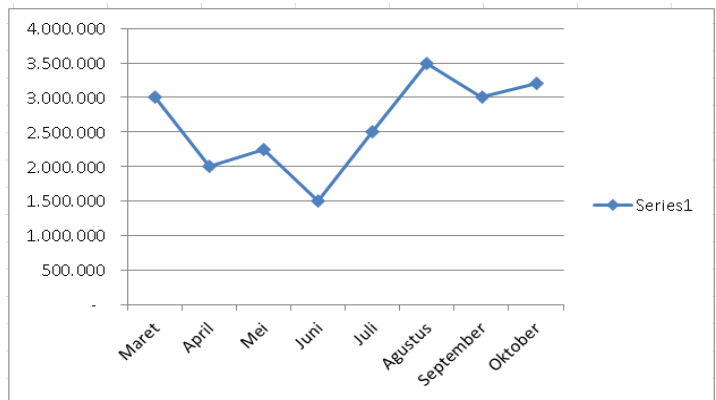

Gambar 6. Trend Omset Mitra, Bulan Juni-Oktober 2021

Selain itu, Mitra saat ini sudah memiliki sejumlah media pemasaran digital, seperti Instagram serta website Tikar ' $O$ ' yang sebagai media promosi dan penjualan produk-produk milik Mitra yang diharapkan menjadi pendukung daya saing produk Mitra dan membantu perluasan cakupan pasar dari produk-prduk Mitra di masa yang akan datang.

\section{KESIMPULAN}

Kegiatan PKM ini menghasilkan dua capaian bagi Mitra mengatasi permasalahan utama yang dihadapinya. Capaian solutif pertama adalah telah tersedianya media pemasaran digital berupa Instagram dan Website usaha sebagai media promosi dan penjualan produk-produk milik Mitra yang diharapkan menjadi pendukung daya saing dan memperluas cakupan pasar dari produk-prduk Mitra. Capaian kedua adalah telah dimilikinya desain logo usaha yang bisa menjadi jati diri sekaligus pembeda produk Mitra dibandingkan produk-produk sejenis milik pesaing.

Dalam upaya selanjutnya unuk mempertinggi daya saing dan mempertahankan keberlanjutan usaha, Mitra disarankan untuk terus berupaya meningkatkan kompetensinya khususnya dalam variasi desain produk sekaligus paduan warna-warna yang menarik. Hal ini dimaksudkan agar mampu merespon permintaan pasar yang terus berubah ataupun berkembang mengikuti trend. Apalagi bila cakupan pasar telah bertambah luas seiring penggunaan media e-commerce dimana tidak lagi berskala lokal atau daerah, tapi bisa menjangkau pasar nasional maupun pasar mancanegara.

Rekomendasi kedua bahwa Mitra perlu selalu bersemangat meningkatkan kemampuannya memanfaatkan media-media teknologi khususnya di era new normal dimana teknologi digital menjadi basis industri saat ini. Hal ini dinilai penting untuk mempertinggi daya saing usaha Mitra di pasar baik saat ni maupun masa yang akan datang. Selain itu, pengembangan usaha Mitra tetap membutuhkan dukungan para stakeholder seperti masyarakat maupun pemerintah desa dimana usaha Mitra berlokasi; perlu adanya sinergitas yang baik untuk memperoleh dukungan pelathan maupun event pameran dari Dekranasda Aceh Timur serta Propinsi Aceh, maupun dari dinas-dinas terkait. Kerjasama dengan para pelaku bisnis seperti BUMN, BUMD, Bumdes ataupun para pengusaha lainnya sangat 
perlu ditingkatkan demi terjalinnya kolaborasi bisnis yang kuat.

\section{UCAPAN TERIMA KASIH}

Tim Pelaksana mengucapkan terima kasih kepada Dirjen Dikti-Ristek Kementerian Pendidikan, Kebudayaan, Riset, dan Teknologi yang telah memberikan pendanaan bagi kegiatan Pengabdian kepada Masyarakat ini melalui Hibah Program Kemitraan Masyarakat (PKM) Tahun 2021. Berikutnya, Tim PKM mengucapkan terima kasih kepada LPPM \& PM Universitas Samudra, Dinas Perindustrian Kab. Aceh Timur, serta Pemerintah Desa Alue Dua Muka O Kec. Idi Rayeuk, yang telah mendukung kegiatan ini sehingga terlaksana dengan baik. Tim PKM secara khusus memberikan apresiasi setinggi-tingginya kepada UKM Kerajinan Anyaman Pandan "Tikar O" Desa Alue Dua Muka O Kec. Idi Rayeuk Kab. Aceh Timur yang telah bersedia menjadi Mitra dan banyak memberikan kontribusi selama kegiatan PKM ini.

\section{DAFTAR PUSTAKA}

Agustina, T. (2020). Pandemi Covid-19: Turbulensi UMKM. Banjarmasin Post, edisi hari Sabtu tanggal 24 Oktober 2020. https://banjarmasin.tribunnews.com/2020/10/01/pandemi-covid-19turbulensi-umkm.

Anggoro, D., Hasugian, H., \& Nofiyani. (2020). Implementasi Digital Marketing pada UKM guna Meningkatkan Pemasaran dan Penjualan Produk di Masa Pandemi Covid-19. JURPIKAT (Jurnal Pengabdian Kepada Masyarakat), 1(2), 384-391. doi: 10.37339/jurpikat.vli3.345.

Dumitriu, D., Militaru, G., Deselnicu, D.C., Niculescu, A., \& Popescu, M.A-M. (2019). A Perspective over Modern SMEs: Managing Brand Equity, Growth and Sustainability through Digital Marketing Tools and Techniques. Sustainability, 11(2111), 1-24. doi: 10.3390/su11072111.

Haryadi, R. N., Anda Rojali, Khumidin, \& M. Fauzan. (2021). Sosialisasi Penggunaan Online Shop berbasis Website di UMKM Cimanggis. Jurnal Pengabdian Masyarakat Madani (JPMM), 1(1), 10-16. https://doi.org/10.51805/jpmm.v1i1.3

Humas Aceh. (2018). Wakil Ketua Dekranasda Aceh Kunjungi Desa Kerajinan. Biro Humas dan Protokol Sekretariat Daerah Aceh Pemerintah Provinsi Aceh, dipublikasikan tanggal 03 September 2018. https://humas.acehprov.go.id/wakil-ketua-dekranasda-aceh-kunjungi-desakerajinan/.

Irham, M. (2020). Virus corona: UMKM diterjang pandemi Covid-19 sampai 'kembang kempis'. BBC News Indonesia, dipublikasikan tanggal 19 Maret 2020. https://www.bbc.com/indonesia/indonesia-51946817.

James, L. (2020). Identifying the Effect of Digital Marketing Channels on the Growth of SME in South Asia: A Case Study on Faheem Haydar Dealzmag. MPRA Paper, No. 105156. https://Mpra.Ub.Uni-Muenchen.De/105156/.

Juhaeri; Rusilowati, U., Hamsinah; Marjohan, M., \& Maddinsyah, A. (2021). 
Pemanfaatan Media Sosial dalam Meningkatkan Daya Saing Produk UKM selama Pandemi Covid-19 pada saat New Normal. Jurnal Pengabdian Dharma Laksana Mengabdi Untuk Negeri, 4(1), 21-25.

Khan, K., \& Panwar, T. (2019). "Achieving Sustainable Competitive Advantage through Brand Makeover". The Marketing Review. 19(3-4): 213-234. https://doi.org/10.1362/146934719X15774562877700.

Kumala, R., \& Junaidi, A. (2020). Strategi Bisnis dan Pemanfaatan Kebijakan Pajak di Masa Pandemi COVID-19 dan Era New Normal (Studi Kasus Pelaku UKM Marketplace). Prosiding Seminar Stiami, 7(2), 98-103.

Luffarelli, J., Mukesh, M. \& Mahmood, A. (2019). "Let the Logo Do the Talking: The Influence of Logo Descriptiveness on Brand Equity". Journal of Marketing Research, 56(5): 862-878. https://doi.org/10.1177/0022243719845000.

Mazurek, M. (2019). "Brand Reputation and its Influence on Consumers' Behavior". Grima, S., Özen, E., Boz, H., Spiteri, J. \& Thalassinos, E. (Ed.). Contemporary Issues in Behavioral Finance (Contemporary Studies in Economic and Financial Analysis, Vol. 101), 45-52. https://doi.org/10.1108/S1569-375920190000101004.

Mufida, A. (2016). Ibu-Ibu Jangan Lupa Anyaman Pandan Tradisi Endatu Aceh. www.goaceh.go, edisi hari Selasa tanggal 12 April 2016. https://www.goaceh.co/artikel/ragam/2016/04/12/ibu-ibu-jangan-lupaanyaman-pandan-tradisi-endatu-aceh.

Taiminen, H., \& Karjaluoto, H. (2015). The Usage of Digital Marketing Channels in SMEs. Journal of Small Business and Enterprise Development, 22(4), 633651. doi: 10.1108/JSBED-05-2013-0073.

Undang-Undang Republik Indonesia No.15 Tahun 2001 tentang Merek. 